\title{
Evaluation of major factors influencing the geochemistry of groundwater using graphical and multivariate statistical methods in Yenagoa city, Southern Nigeria
}

\author{
K. S. Okiongbo $\cdot$ R. K. Douglas
}

Received: 30 August 2013/Accepted: 20 February 2014/Published online: 17 March 2014

(C) The Author(s) 2014. This article is published with open access at Springerlink.com

\begin{abstract}
To achieve a better understanding of the nature of the factors influencing groundwater composition as well as to specify them quantitatively, conventional graphical and multivariate statistical analysis (principal component analysis) were applied on hydrochemical data consisting of 51 groundwater samples collected from domestic boreholes in Yenagoa city, Bayelsa State, Nigeria. The mode of study includes analysis of major ion contents and other chemical parameters such as $\mathrm{pH}$, total dissolved solids and electrical conductivity of the groundwater samples. The PCA yielded three principal components explaining $78.38 \%$ of the total variance of the 11 parameters. The three components are interpreted as controlled by the natural weathering of existing silicate rocks, reverse ion-exchange processes and oxidation reactions which are further supported by the scatter diagrams, ionic signatures and mechanisms controlling the water chemistry diagrams as the common factors influencing the groundwater hydrogeochemical character. Limited anthropogenic influence on the groundwater composition has also been noticed in the study area. The groundwater poses no threat to human health because the concentrations of physico-chemical parameters that can be used to evaluate drinking water quality are within World Health Organisation standard specification. The groundwater in the area is fresh, high salinity and low sodium in nature.
\end{abstract}

K. S. Okiongbo $(\square)$

Department of Geology and Physics, Niger Delta University, Wilberforce Island, Bayelsa State, Nigeria

e-mail: okenlani@yahoo.com

R. K. Douglas

School of Applied Sciences, Cranfield University, Cranfield, Bedforshire MK 43 OAL, UK
Keywords Multivariate statistical analysis - R-mode factor analysis · Groundwater quality · Hydrogeochemistry · Yenagoa

\section{Introduction}

Hydrogeochemical investigations to characterise groundwater and assess its chemical quality often involve substantially large amount of base information concerning groundwater chemistry. Groundwater chemistry, in turn, depends on a large number of factors, such as general geology, degree of chemical weathering of the various rock types, quality of recharge water and inputs from sources other than water-rock interaction. Such factors and their interactions result in a complex groundwater quality. Thus, the characterisation and interpretation of various groundwater parameters is often a complex problem. Several conventional methods of data analysis are often used for the interpretation and presentation of results (Hem 1989), e.g. histograms, stiff, trilinear, semilogarithmic diagrams and many others (Lloyd and Heathcote 1985). The use of these graphical methods to interpret aquatic chemistry is limited to two dimensions, besides, deal only with a limited number of variables responsible for the groundwater chemistry and can produce biased results (Guler et al. 2002).

To overcome the limitations of these conventional methods, multivariate statistical analysis such as principal component analysis had been widely used for characterizing and interpreting geochemical data. Such analyses are especially useful because in addition to revealing the interaction among the variables, it also attempts to simplify the complex and diverse relationships that exist among a set of observed variables (i.e. the concentrations of 
physico-chemical constituents) by revealing common and unobserved factors (i.e. the underlying physico-chemical constituents and/or biological processes in the groundwater system) that link together with the seemingly unrelated variables (Lee et al. 2001). Reeder et al. (1972) identified the likely weathering processes controlling the chemical composition of surface waters of Mackenzie River drainage basin Canada. Ashley and Lloyd (1978) used factor analysis to evaluate the hydrogeochemical process in the Santiago basin of Chile and the Derbyshire Dome of England. Lawrence and Upchurch (1982) also used the technique to delineate the zones of natural recharge to groundwater in the Florida aquifer. Ruiz et al. (1990) suggested that the basic purpose of such an analysis was to study the hydrogeochemistry of aquifers by simplifying the numerous and complex groundwater data into a set of factors, few in number which can explain a large amount of the variance of the analytical data and also indicate the source of origin of various ions present in water. Earlier studies carried out in the study area are on the geochemistry of groundwater (Amadi et al. 1987), prospecting of groundwater resources (Okiongbo and Ogobiri 2011), and groundwater quality with respect to drinking and agricultural purposes (Okiongbo and Douglas 2013). These studies mainly focus on chemical composition of groundwater using conventional methods only.

In this study, we carry out a hydrochemical evaluation of an alluvial aquifer system with an objective of delineating the various factors controlling the water chemistry and general suitability of the groundwater for domestic and drinking purposes using conventional graphical and multivariate statistical methods.

\section{Description of the study area}

\section{Location and climate}

The study area entails Yenagoa city, part of Southern Ijaw and Ogbia Local Government Areas in Bayelsa State and lies between longitudes $006^{\circ} 05^{\prime}$ and $006^{\circ} 040^{\prime}$ East of the prime meridian and latitudes $04^{\circ} 23.3^{\prime}$ and $04^{\circ} 38.2^{\prime}$ North of the equator within the coastal area of the recent Niger Delta (Fig. 1). Bayelsa State is located in the southern end of Nigeria and is within the Niger Delta Basin. It is bounded in the north by Rivers State, in the west by Delta State and in the south by the Bight of Bonny. The study area has an areal extent of about $150 \mathrm{~km}^{2}$. The study area has a tropical rain forest climate characterised by two seasons, namely the wet or rainy season and the dry season. The rainy season lasts for about 7 months between April and October with an intervening dry period in August. The dry season lasts for about 4 months, between November and March. The temperature varies between 25 and $32{ }^{\circ} \mathrm{C}$. The mean annual rainfall is about 4,500 mm (Akpokodje 1986); about $85 \%$ of the mean annual rain falls in the wet season.

Physiography and drainage

The study area consists of alluvial deposits and an extensive, low-lying, typical deltaic plain with essentially flat topography which, in conjunction with the high annual rainfall, is responsible for the extremely poor drainage conditions and the widespread development of marshes and backswamps. This area is usually submerged during the wet season where flood waters range from 0.5 to $4 \mathrm{~m}$ deep (Akpokodje 1986). There are a number of perennial streams, oxbow lakes and rivers in the area e.g. Kolo Creek, Epie Creek, Yenagoa and Nun river, etc. They all form a network which empties to the Atlantic Ocean through Nun River Estuary. These rivers are mostly turbid during the wet season possibly due to discharge of clay and silt (Amadi et al. 1987). The natural vegetation of the study area is that of the rain forest but this has been destroyed by the activities of man such as bush burning, farming, construction and illegal crude oil refining activities. The vegetation consists of various kinds of evergreen trees, including palms trees and a variety of shrubs. More than $70 \%$ of the inhabitants of the study area are engaged in subsistent farming and fishing.

\section{Geology}

The study area (Fig. 1) lies within the fresh water forests, swamps and backswamp geomorphic unit of the Niger Delta. The Niger Delta is basically an alluvial plain formed by the deposition and built-up of fine-grained sediments eroded and transported to the area by the River Niger and its tributaries (Fig. 1). The regional geology of the Niger Delta is relatively simple consisting of three lithostratigraphic units, Akata, Agbada and Benin Formations, overlain by various types of quaternary deposits (Short and Stauble 1967; Wright et al. 1985; Kogbe 1989).

The quaternary deposits are considered universally to be the recent expressions of and continuation of the Benin Formation and consist of medium to coarse-grained sands, sandy clays, silts and subordinate, lensoid clay bands thought to have been deposited during quaternary interglacial marine transgressions (Durotoye 1989). Amajor (1991) has shown that they are an admixture of fluvial/tidal channel, tidal flats and mangrove swamp deposits. The sands are micaceous and feldspathic, subrounded to angular in texture and constitute good aquifers. However, depth to occurrence and thickness is irregular and may not be 
Fig. 1 The major geomorphological units of the Niger Delta (After Akpokodje 1986)

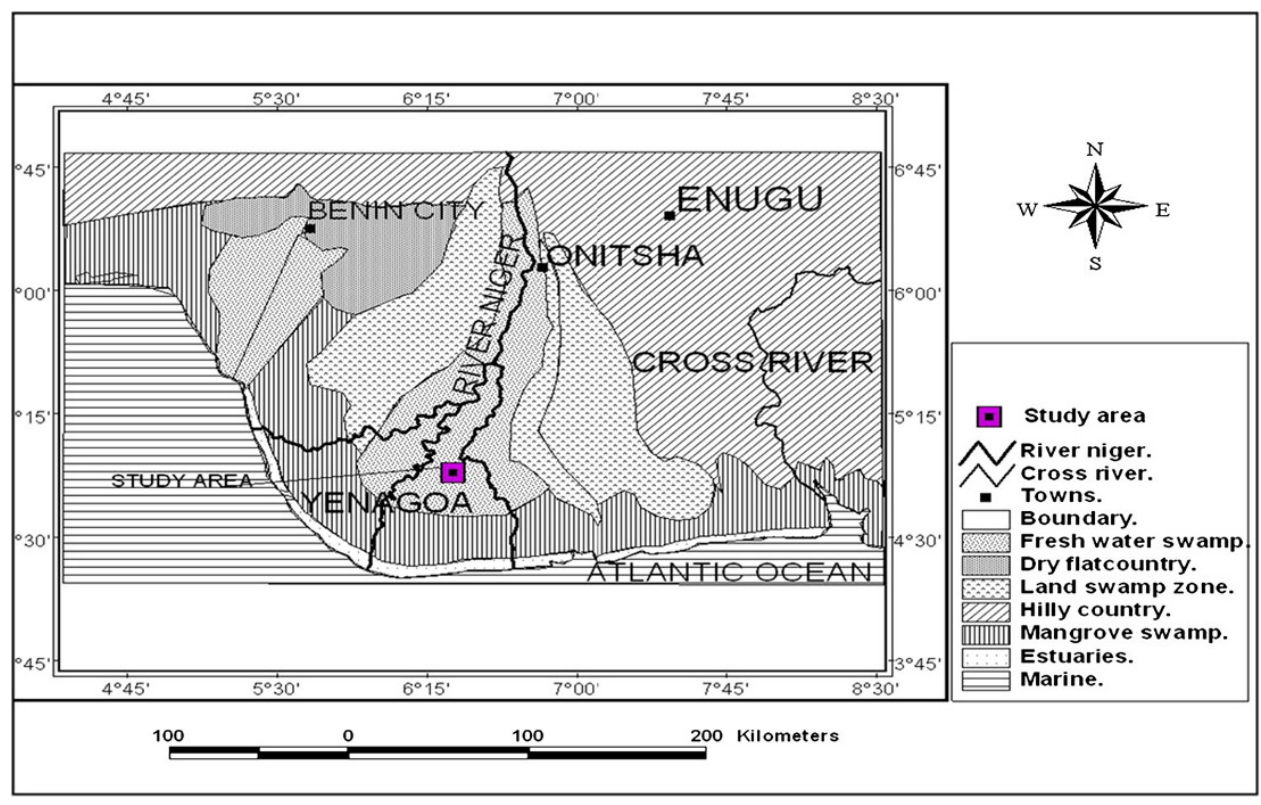

predicted with accuracy within the study area due to rapid horizontal and vertical facie changes. Groundwater occurs generally under water table conditions where the lensoid clays attain adequate thickness.

The Benin Formation is essentially fluvial in origin comprising unconsolidated, massive and porous fresh water bearing sands with localized clay/shale beds. The sand-clay intercalations are indicative of a multi-aquifer system. The thickness of the Benin Formation is about $2,100 \mathrm{~m}$ on the average. The age of this Formation ranges from Miocene to Recent. Onyeagocha (1980) reported that the rocks are made up of $95 \%$ quartz grains, $\mathrm{Na}+$ mica $1-2.5 \%$, feldspar $0-1.0 \%$ and dark coloured minerals $2.3 \%$. Water table in large sections of the Niger Delta is close to the surface but subject to spatial and seasonal variations. In the study area, the water table is about $3-4 \mathrm{~m}$ during the dry season. During the wet season, the water table rises considerably, in some cases, to the ground surface. The Agbada Formation underlies the Benin Formation. Its thickness varies from 300 to $4,500 \mathrm{~m}$ (Short and Stauble 1967). This Formation consists predominantly of unconsolidated pebbles, and very coarse to fine-grained sand units with subordinate shale beds. Underneath the Agbada Formation is the Akata Formation of Eocene to recent age (Amadi et al. 1987), which is made up of shales with local inter-bedding of sands and siltstones. It was deposited in a typically marine environment with maximum thickness of about 6,100 m (Ofoegbu 1989).

\section{Hydrogeology}

The Coastal Plain Sands of the Benin Formation are the main regional and most important aquifer in the study area.
Groundwater in the Coastal Plain Sands occurs mainly under phreatic (unconfined) conditions. The lithology of this formation is dominated by loose sands (fine-mediumcoarse), while gravel and pebbles are minor components. Thin clay horizons and lenses create discontinuities in the vertical and lateral continuity of the porous sands and gravel. This condition results in the presence of local perched aquifers. Rainfall is the direct recharge source of the groundwater. The transmissivity values for the aquifer range from $1.05 \times 10^{-2}$ to $11.3 \times 10^{-2} \mathrm{~m}^{2} / \mathrm{s}$, while the coefficient of storage varies between $1.07 \times 10^{-4}$ and $3.53 \times 10^{-4}$ and specific capacity values lie between 19.01 and $139.8 \mathrm{~m}^{3} / \mathrm{h} / \mathrm{m}$ drawdown (Amajor 1991). These values suggest that the aquifers have very good capacity to transmit groundwater. The groundwater quality is very good and compares favourably with WHO standards for drinking water. However, relatively high iron and chloride values though localized are observed.

\section{Method of study}

Groundwater samples were collected from 51 domestic boreholes spread over the study area (Fig. 2) in 3 weeks in the month of February, 2013, and were analysed within $24 \mathrm{~h}$. A global positioning system (GPS) was used for location and elevation readings. The samples were collected in polyethylene bottles for the analysis of total hardness, total dissolved solids (TDS) and major ions such as $\mathrm{Na}, \mathrm{K}, \mathrm{Ca}, \mathrm{Mg}, \mathrm{HCO}_{3}, \mathrm{CO}_{3}, \mathrm{Cl}$ and $\mathrm{SO}_{4}$ in the laboratory. All samples were analysed using standard procedures (APHA 1995). Electrical conductivity (EC) and $\mathrm{pH}$ of groundwater samples were measured in the field 
Fig. 2 Map of study area showing borehole locations

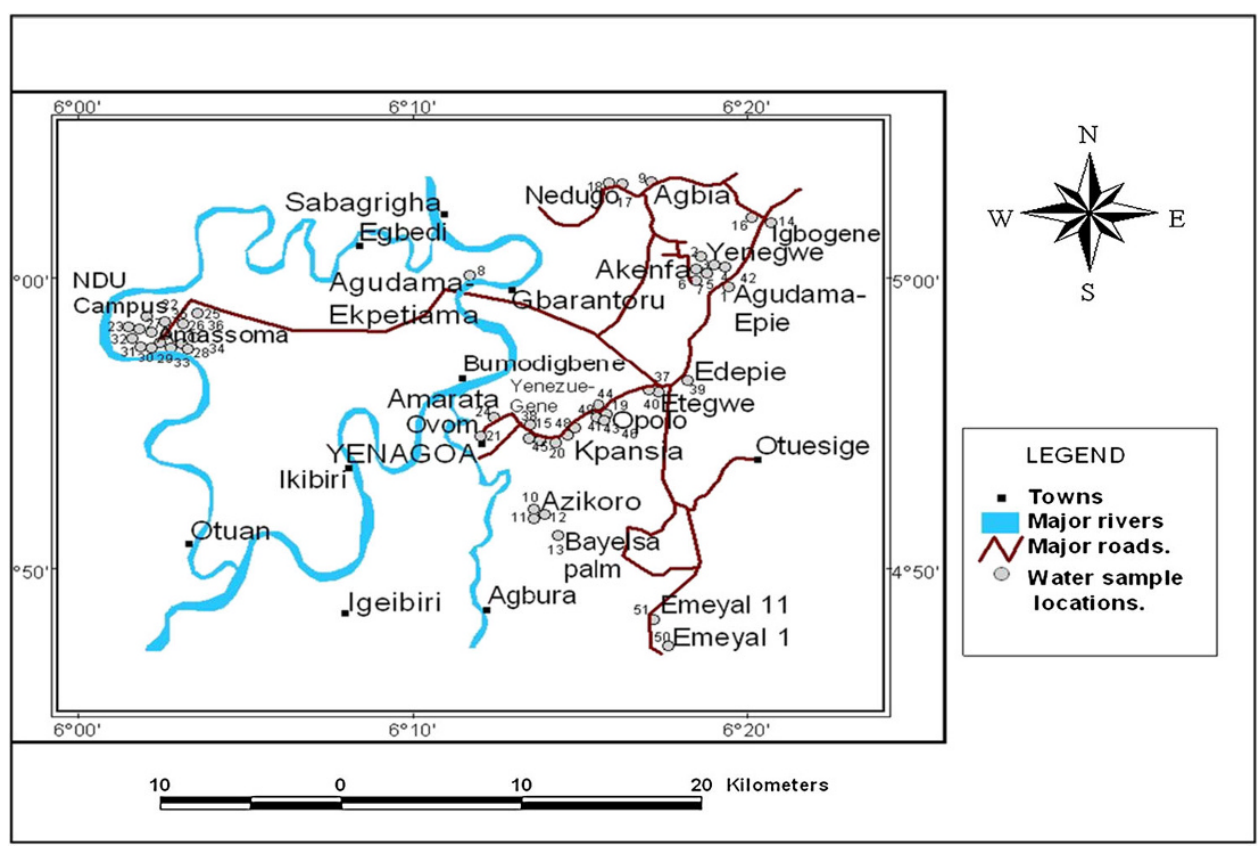

immediately after sample collection using portable field kits (Hach's CO 150 Conductivity/TDS metre and $\mathrm{pH}$ metre, respectively). Major ions like sulphate $\left(\mathrm{SO}_{4}{ }^{2-}\right)$ were determined by spectrophotometric turbidimetry. The method is based on the principle of formation of barium sulphate in the presence of (acidified $\mathrm{HCl}$ ) barium chloride. The process is enhanced in the presence of glycerol or other organic compound. The absorbance of the colloidal solution was measured against a standard on UV-visible Spectrophotometer. Calcium $\left(\mathrm{Ca}^{2+}\right)$ and magnesium $\left(\mathrm{Mg}^{2+}\right)$ were determined titrimetrically using EDTA; chloride $\left(\mathrm{Cl}^{-}\right)$was determined by standard $\mathrm{AgNO}_{3}$ titration; bicarbonate $\left(\mathrm{HCO}_{3}{ }^{-}\right)$was determined by titration with $\mathrm{HCL}$; sodium $\left(\mathrm{Na}^{+}\right)$and potassium $\left(\mathrm{K}^{+}\right)$were measured by flame photometry; nitrate $\left(\mathrm{NO}_{3}{ }^{-}\right)$was determined by colourimetry with a UV-visible spectrophotometer (brucine method) while iron was determined by colourimetry with a UV-visible spectrophotometer at $520 \mathrm{~nm}$. Iron results represent ferrous iron. In general, ion balance error of the samples was observed to be within the acceptable range of $\pm 10 \%$.

The data was analysed using multivariate statistical technique (principal component analysis) to identify the hydrogeochemical processes which result in the variations in the chemical composition of groundwater. Saturation indices of groundwater with respect to the mineral phases and the chemical facies were determined using the computer programmes PHREEQC and AQUACHEM, respectively.

The obtained matrix of hydrogeochemical data was subjected to multivariate analytical technique. Principal component analysis (PCA) was used here as a numerical method of discovering variables that are more important than others for representing parameter variation and identifying hydrogeochemical processes. The entire dataset was first standardized and arranged in correlation coefficient matrix with normal distribution in all variables. The principal component approach started by extracting eigenvalues and eigenvectors of the correlation matrix and then less important of these was discarded (Davis 1986). The eigenvalues calculated quantify the contribution of a factor to the total variance. The percentages were also computed. The contribution of a factor is significant when the eigenvalue is greater than unity. The factors that are significant (with eigenvalues more than one and explaining for the higher percentage of the variability of the data) were noted. The factor loadings were calculated by a varimax rotation technique in such a way that they are closer to $+1,0,-1$, representing positive contribution, no contribution and negative contribution. They suggest the dominance of the corresponding variables which, when projected onto the data, give factor scores.

\section{Results and discussion}

Groundwater chemistry

The physico-chemical compositions of the groundwater samples are given in Table 1, and Table 2 gives the descriptive statistical measures such as minimum, maximum, mean and standard deviation values of various parameters investigated along with the World Health Organisation standards (WHO 2004). In the groundwater 
Table 1 Hydrogeochemical analysis of groundwater samples

\begin{tabular}{|c|c|c|c|c|c|c|c|c|c|c|c|c|c|c|c|c|c|c|c|}
\hline $\mathrm{N}$ & ode & $\mathrm{H}$ & $\mathrm{C}$ & DS & TA & TH & $a^{+}$ & $\mathrm{K}^{+}$ & $2+$ & $2+$ & $\mathrm{Fe}$ & $1^{-}$ & $2-$ & $U_{3}$ & & & & 3041 & SAl \\
\hline & & & & & & & & & & & & & & & & & & & 2.7 \\
\hline & & & & & & & & & & & & & & & & & & & .1 \\
\hline & H3 & 8 & & & & & & & & & & & & & & & & & .8 \\
\hline & $3 \mathrm{H} 4$ & & & & & & & & & & & & & & & & & & .6 \\
\hline & BH5 & 7 & & & .0 & & & & & 3.1 & & 12.5 & 1. & & 72.0 & & & & 2.2 \\
\hline & H6 & & 8.0 & & .0 & & & 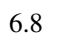 & & & & 5 & & & 3.3 & & & & 2.1 \\
\hline & H7 & 03 & & & & & & & & & & 4 & & & & -6.3 & & & 3.1 \\
\hline & H8 & 8 & 0 & & .0 & & & & & & & & & & & & & & 3.1 \\
\hline & H9 & 20 & 520 & & 0 & 4.0 & & & & & & & & & & & & & 3.3 \\
\hline 0 & BH10 & 24 & 0.0 & 4 & 8.0 & & & & & 3 & & & & & & & & & 1.7 \\
\hline 1 & H11 & & .0 & $18 \quad$ & .0 & 00 & & 3.4 & 6. & 2 & & 14.4 & & & & & -0.7 & & 3.5 \\
\hline 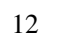 & H12 & & .0 & & & & & & & & & 14.8 & & & & - & & & 2.9 \\
\hline & 113 & & & & & & & & & & & & & & & & & & .3 \\
\hline 4 & $\mathrm{H} 14$ & 0 & 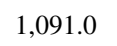 & 546.0 & & 120.0 & 42 & .6 & 5 & 2. & & 21.2 & 4 & & .9 & & & & 5.4 \\
\hline 5 & 3H15 & 31 & 8.0 & $20 S$ & & & & & & 3.46 & & 16.0 & & & & -( & -0.4 & & 1.3 \\
\hline 6 & & & & & & & & & & & & & & & & & & & .1 \\
\hline 7 & $\mathrm{H} 17$ & 87 & 0 & 49.0 & 0 & & & 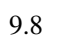 & & 6 & & 21.6 & & 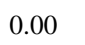 & & - & & & 1.3 \\
\hline 8 & H18 & 00 & & & & & & & & & & & & & & & & & .0 \\
\hline 9 & $\mathrm{H} 19$ & 4 & 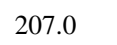 & & & & & & & 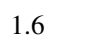 & & & & & & & 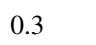 & & .6 \\
\hline 0 & BH20 & 34 & 0.0 & & 0 & & & & & 6. & & 39.1 & 6 & & & & & & 3.3 \\
\hline & [21 & & & & & & & & & & & & & & & & & & .2 \\
\hline & 122 & & & & & & & 65 & & 1.8 & & 1 & 4. & & & & & & 2.1 \\
\hline 3 & $\mathrm{H} 23$ & 19 & 9.0 & & 2.0 & & $1^{\prime}$ & & 5. & 4 & & 6. & 2 & & & - & -( & & 1.9 \\
\hline & 124 & & & & & & & & & & & & & & & & & & 0.9 \\
\hline 25 & $\mathrm{H} 25$ & 6 & 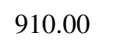 & & 0 & 000 & 0 & 760 & & 3 & 0 & 50 & & & & & & & 1.1 \\
\hline 6 & I26 & & & & & & & & & & & & & & & & & & .7 \\
\hline & 27 & & & & & & & & & & & & & & & & & & 6 \\
\hline 8 & $\mathrm{H} 28$ & 22 & 200.00 & 0 & 6.00 & 0 & 9. & 12.60 & 18.80 & 6.70 & 2.00 & 17.70 & 5. & & & & & & 0.7 \\
\hline & & & & & & & & & & & & & & & & & & & 6 \\
\hline & 330 & & & & & & & & & & & & & & & & & & .8 \\
\hline 1 & 331 & 46 & 0 & 0 & 00 & 0 & 8.80 & 0 & 0 & 8 & 7.38 & 1 & 4.8 & 0 & 9.4 & & & & 0.6 \\
\hline & & & & & & & & & & & & & & & & & & & 0.9 \\
\hline & H33 & 4 & 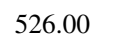 & & & & & & & & & & & & & & & & 0.8 \\
\hline & 4 & & & & & & & & & & & & & & & & & & .6 \\
\hline & & & & & & & & & & & & & & & & & & & .5 \\
\hline 6 & 136 & 93 & 0 & 700 & 00 & 5.00 & 6.40 & 7.40 & 2.80 & 6.90 & 0 & 00 & & 3.70 & & & & 0.04 & 0.7 \\
\hline 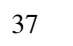 & 137 & & 0 & & 42.00 & .00 & 38.90 & 00 & & 5 & 26 & & & 4.6 & & & & & 3.1 \\
\hline & & & & & & & & & & & & & & & & & & & 1.3 \\
\hline 9 & 9 & 72 & 00 & & & & 8.50 & & 5.4 & 0 & 0 & 9 & & & 2.80 & -( & - & 9 & 1.0 \\
\hline 0 & $\mathrm{H} 40$ & & & & & & & 4.20 & & & & & & & & & & & 1.4 \\
\hline 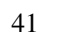 & BH41 & 0 & & & & & & & & & & & & & & & & & 0.7 \\
\hline 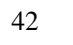 & & & & & & & & & & & & & & & & & & & .7 \\
\hline 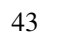 & 143 & U & & & & & & & & & & & & & & & & & 3.0 \\
\hline 44 & BH44 & 69 & & & & & & 10.88 & & & & & & 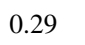 & & & & & .6 \\
\hline 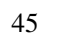 & & & & & & & & & & & & & & & & & & & .8 \\
\hline 10 & BH46 & 4 & & & & & & & & & & & & & & & 0.00 & & 0.5 \\
\hline 47 & & & & & & & & 4.70 & & & & & & & & & .45 & & 0.1 \\
\hline & & & & & & & & & & & & & & & & & & & .3 \\
\hline 19 & BH49 & .55 & 94.00 & 147.00 & 13.00 & 12.60 & 4.28 & 1.85 & 3.50 & 2.80 & 0.25 & 12.30 & 12.60 & 0.28 & 5.50 & 0.33 & 0.32 & 1.02 & 0.8 \\
\hline & & 6.35 & & & & & & & & & & & & & & & & 46 & .5 \\
\hline 1 & BH51 & 6.33 & 909.00 & 455.00 & 28.50 & 8.60 & 38.50 & 12.60 & 18.50 & 6.70 & 3.50 & 54.80 & 28.80 & 0.28 & 14.50 & -0.29 & -0.54 & 0.53 & 2.8 \\
\hline
\end{tabular}

All parameters have been expressed as $\mathrm{mg} / \mathrm{L}$, except $\mathrm{pH}$ and EC. The unit of EC is $\mu \mathrm{S} / \mathrm{cm}$ while total alkalinity (TA) and total hardness (TH) is $\mathrm{mg} / \mathrm{L}$ $\mathrm{CaCO}_{3}$. The iron results represent ferrous iron and SAR is expressed in meq/l 
samples, $\mathrm{pH}$ value ranges from 5.55 to 6.93 with an average of 6.93. The decrease in $\mathrm{pH}$ is primarily due to oxidation of organic matter and also due to anthropogenic activities (Krishnaraj et al. 2011). Concentrations of TDS, a measure of groundwater quality ranged from 51 to $1,410 \mathrm{mg} / \mathrm{L}$ with an average of $388.3 \mathrm{mg} / \mathrm{L}$. According to TDS classification, $90 \%$ of the samples belong to fresh water type (TDS $<1,000 \mathrm{mg} / \mathrm{L}$ ) and the remaining $10 \%$ represent brackish water (TDS $>1,000 \mathrm{mg} / \mathrm{L}$ ). The electrical conductivity values range from 102 to $2,820 \mu \mathrm{S} / \mathrm{cm}$, with an average of $765.9 \mu \mathrm{S} / \mathrm{cm}$.

Tables 1 and 2 show that the major cations $\mathrm{Na}^{+}, \mathrm{K}^{+}$, $\mathrm{Ca}^{2+}, \mathrm{Mg}^{2+}$ and $\mathrm{Fe}$ are all low except iron with mean concentrations of $17.4,9.9,9.9,5.2$ and $3.18 \mathrm{mg} / \mathrm{L}$, respectively. The major anions $\mathrm{HCO}_{3}{ }^{-}, \mathrm{Cl}^{-}, \mathrm{SO}_{4}{ }^{2-}$ and $\mathrm{NO}_{3}{ }^{-}$are also low with mean concentrations of $50 \mathrm{mg} / \mathrm{L}$, $19.2 \mathrm{mg} / \mathrm{L}, 6.1 \mathrm{mg} / \mathrm{L}$ and $1.12 \mathrm{mg} / \mathrm{L}$, respectively. The results obtained show that the concentration of dissolved major cations and anions in the groundwater varies spatially and mass abundance was in the order of: $\mathrm{Na}^{+}>\mathrm{Ca}^{2+}>\mathrm{K}^{+}>\mathrm{Mg}^{2+}>\mathrm{Fe}$ for cations and $\mathrm{HCO}_{3}{ }^{-}>\mathrm{Cl}^{-}>\mathrm{SO}_{4}{ }^{2-}->\mathrm{NO}_{3}{ }^{-}$for anions. The average concentrations of the major ions in the groundwater indicate that the groundwater of the area is suitable for drinking in all samples except iron. The analytical data plotted on the EC versus SAR (sodium adsorption ratio $=\mathrm{Na}^{+} /\left(\left[\mathrm{Ca}^{2+}+\mathrm{Mg}^{2+}\right] / 2\right)^{0.5}$ diagram (Fig. 3) illustrates that most of the groundwater samples fall mainly in the field of $\mathrm{C} 2-\mathrm{S} 1$ and $\mathrm{C} 3-\mathrm{S} 1$ indicating medium to high salinity and low sodium water. Thus, the groundwater in the area can be used for irrigation on almost all types of soil with little danger of exchangeable sodium.

A Piper diagram was plotted to examine the hydrochemical water types (Fig. 4). The Piper diagram shows that the chemical composition of the groundwater in the study area is composed of six main types: $\mathrm{Ca}-\mathrm{Cl}, \mathrm{Ca}-$ $\mathrm{HCO}_{3}-\mathrm{Cl}, \mathrm{Ca}-\mathrm{Na}-\mathrm{Cl}, \mathrm{Ca}-\mathrm{Na}-\mathrm{HCO}_{3}-\mathrm{Cl}, \mathrm{Ca}-\mathrm{Na}-\mathrm{HCO}_{3}$ and $\mathrm{Na}-\mathrm{HCO}_{3}$. About $52.2 \%$ groundwater is dominated by the alkalis $\left(\mathrm{Na}^{+}\right.$and $\left.\mathrm{K}^{+}\right)$over the alkaline earths $\left(\mathrm{Ca}^{2+}\right.$ and $\left.\mathrm{Mg}^{2+}\right)$ and in $54.2 \%$ of samples, weak acids $\left(\mathrm{HCO}_{3}{ }^{-}\right)$ exceed strong acids $\left(\mathrm{SO}_{4}{ }^{-}\right.$and $\left.\mathrm{Cl}^{-}\right)$.

\section{Hydrogeochemical evaluation}

The geochemical variations in the ionic concentrations in the groundwater can easily be understood when they are plotted along an $X-Y$ coordinate (Guler et al. 2002). Results from the chemical analyses were used to identify the geochemical processes and mechanisms in the groundwater aquifer system. Gibbs plots of TDS versus the ion ratios $\mathrm{Na} /(\mathrm{Na}+\mathrm{Ca})$ and $\mathrm{Cl} /\left(\mathrm{Cl}+\mathrm{HCO}_{3}\right)$ (Fig. 5) show that all data points fall on the intermediate area between the rock dominance end member and evaporation/precipitation dominance end member indicating that rock weathering was the dominant process controlling the major ion composition of groundwater in the study area (Gibbs 1970).

The molar ratio of $\mathrm{Na} / \mathrm{Cl}$ for groundwater samples of the study area generally ranges from 0.11 to 9.09 (Fig. 6a). Samples having $\mathrm{Na} / \mathrm{Cl}$ ratio greater than one indicate excess sodium, which might have come from silicate weathering which is dominant in the aquifer materials of the study area. If silicate weathering is a probable source of sodium, the groundwater samples would have $\mathrm{HCO}_{3}{ }^{-}$as the most dominant abundant anion (Rogers 1989). This is because the reaction of feldspar minerals with carbonic acid in the presence of water releases $\mathrm{HCO}_{3}{ }^{-}$(Elango et al. 2003). Table 1 shows that $\mathrm{HCO}_{3}{ }^{-}$is the dominant anion in the groundwater of the study area; hence silicate weathering was the primary process responsible for the release of $\mathrm{Na}^{+}$into the groundwater. However, samples with a Na/Cl ratio around and less than one indicate the possibility of some other chemical processes, such as ion exchange (Elango et al. 2003).

Cerling et al. (1989) and Fisher and Mulican (1997) observed that the plot of $\mathrm{Ca}^{2+}+\mathrm{Mg}^{2+}$ vs $\mathrm{SO}_{4}+\mathrm{HCO}_{3}{ }^{-}$ is a major indicator to identify ion-exchange process. If ion exchange is the process, the points tend to shift to the right side of the plot due to an excess of $\mathrm{SO}_{4}+\mathrm{HCO}_{3}{ }^{-}$. If reverse ion exchange is the process, points tend to shift to the left side due to excess of $\mathrm{Ca}+\mathrm{Mg}$ over $\mathrm{SO}_{4}+\mathrm{HCO}_{3}{ }^{-}$. The plot of the $\mathrm{Ca}^{2+}+\mathrm{Mg}^{2+}$ vs $\mathrm{SO}_{4}+\mathrm{HCO}_{3}^{-}$(Fig. 6b) in the study area shows that most of the groundwater samples of the alluvial aquifer are clustered around and above the 1:1 line, indicating reverse ion exchange (El-Sayed et al. 2012).

The evidence for cation exchange is also given by bivariate plot of $\mathrm{Ca}^{2+}+\mathrm{Mg}^{2+}-\mathrm{HCO}_{3}-\mathrm{SO}_{4}$ as a function of $\mathrm{Na}^{+}+\mathrm{K}^{+}-\mathrm{Cl}^{-}$, as shown in Fig. 6c. If cation exchange was not a significant reaction in the aquifer system, all data would plot close to the origin (McLean et al. 2000). But if cation exchange was an important composition controlling process, the relation between these two parameters should be linear with a slope of -1 . Figure $6 \mathrm{c}$ indicates an increase in $\mathrm{Na}^{+}+\mathrm{K}^{+}$related to a decrease in $\mathrm{Ca}^{2+}+\mathrm{Mg}^{2+}$ or an increase in $\mathrm{HCO}_{3}+\mathrm{SO}_{4}$. All data plot close to a straight line with a slope of -0.776 , indicating that some of the $\mathrm{Na}^{+}, \mathrm{Ca}^{2+}$ and $\mathrm{Mg}^{2+}$ participate in the ion-exchange reaction (Garcia et al. 2001). Furthermore, ion exchange and reverse ion exchange occurring in the groundwater were confirmed by two basic exchange indices, namely the chloro alkaline indices (CAI-1 and CAI-2):

$$
\begin{aligned}
\text { CAI-1 }= & {\left[\mathrm{Cl}^{-}-\left(\mathrm{Na}^{+}+\mathrm{K}^{+}\right)\right] / \mathrm{Cl}^{-} } \\
\text {CAI-2 }= & {\left[\mathrm{Cl}^{-}-\left(\mathrm{Na}^{+}+\mathrm{K}^{+}\right)\right] / } \\
& \left(\mathrm{SO}_{4}+\mathrm{HCO}_{3}+\mathrm{CO}_{3}+\mathrm{NO}_{3}\right)
\end{aligned}
$$


Table 2 Descriptive statistics of analysed groundwater samples compared with standards

\begin{tabular}{lllllll}
\hline Parameter & No of Samples & Minimum & Maximum & Mean & Standard Deviation & WHO 2004 maximum permissible limit \\
\hline $\mathrm{pH}$ & 51 & 5.55 & 6.93 & 6.13 & 0.34 & $6.5-8.5$ \\
$\mathrm{EC}(\mu \mathrm{S} / \mathrm{cm})$ & 51 & 102 & 2,820 & 765.9 & 601.78 & 1,400 \\
$\mathrm{TDS}(\mathrm{mg} / \mathrm{L})$ & 51 & 51 & 1,410 & 388.3 & 300.87 & 1,000 \\
$\mathrm{TA}(\mathrm{mg} / \mathrm{L})$ & 51 & 2 & 65 & 24.4 & 14.46 & 500 \\
$\mathrm{TH}(\mathrm{mg} / \mathrm{L})$ & 51 & 3 & 265 & 53 & 62.60 & 200 \\
$\mathrm{Na}^{+}(\mathrm{mg} / \mathrm{L})$ & 51 & 1.1 & 60.4 & 17.4 & 13.65 & 55 \\
$\mathrm{~K}^{+}(\mathrm{mg} / \mathrm{L})$ & 51 & 1.02 & 30.4 & 9.9 & 5.83 & 75 \\
$\mathrm{Ca}^{2+}(\mathrm{mg} / \mathrm{L})$ & 51 & 1.2 & 40.5 & 9.9 & 8.05 & 50 \\
$\mathrm{Mg}^{2+}(\mathrm{mg} / \mathrm{L})$ & 51 & 0.5 & 21.8 & 5.2 & 3.66 & 0.3 \\
$\mathrm{Fe}^{(\mathrm{mg} / \mathrm{L})}$ & 51 & 0.01 & 12.3 & 3.18 & 4.27 & 250 \\
$\mathrm{Cl}^{-}(\mathrm{mg} / \mathrm{L})$ & 51 & 2.9 & 54.8 & 19.2 & 13.80 & 400 \\
$\mathrm{SO}_{4}{ }^{2-}(\mathrm{mg} / \mathrm{L})$ & 51 & 0.5 & 28.8 & 6.1 & 5.89 & 50 \\
$\mathrm{NO}_{3}{ }^{-}(\mathrm{mg} / \mathrm{L})$ & 51 & 0.01 & 8.56 & 1.12 & 1.94 & - \\
$\mathrm{HCO}^{-}{ }^{-}(\mathrm{mg} / \mathrm{L})$ & 51 & 6.2 & 300.8 & 50 & 62.13 & \\
\hline
\end{tabular}

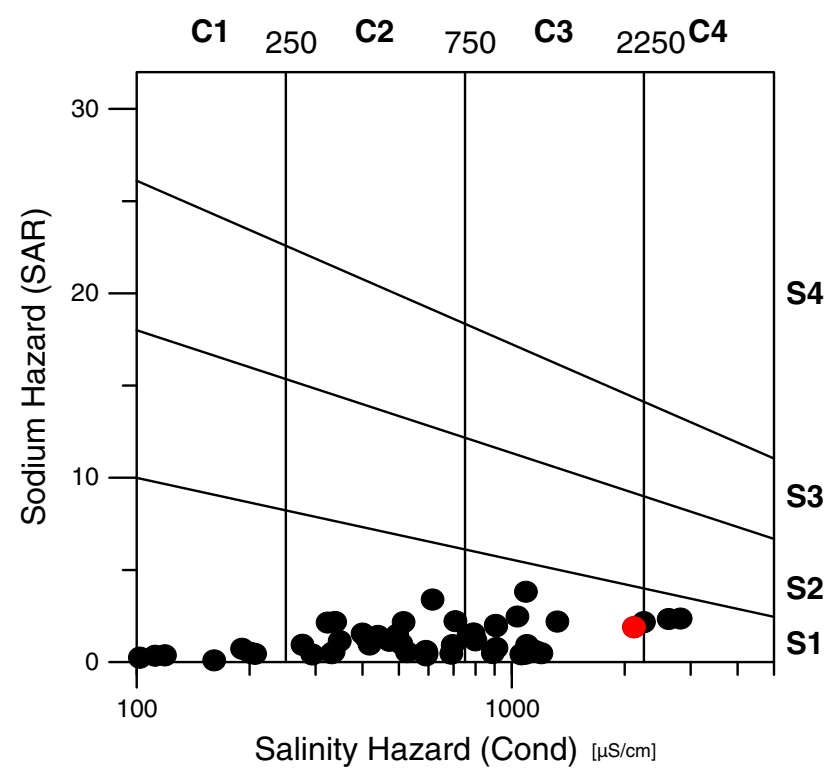

Fig. 3 Wilcox salinity diagram

(all values are expressed in $\mathrm{meq} / \mathrm{L}$ ). If there was ion exchange of $\mathrm{Na}^{+}$and $\mathrm{K}^{+}$from water with magnesium and calcium in the rock, then the exchange is known as direct when the indices are positive. If the exchange is in the reverse order, then the exchange is indirect and the indices are found to be negative (Schoeller 1967). The calculated chloro alkaline indices are presented in Table 1. It was observed that $75 \%$ of the groundwater samples show negative ratios and thus exhibit a reverse ion exchange.

The area of study is characterised by shallow water table, underlain by very pyritic carbonaceous (peat, lignite and organic matter) wetland sediments. These sediments contain inorganic sulphides including pyrite and other iron-

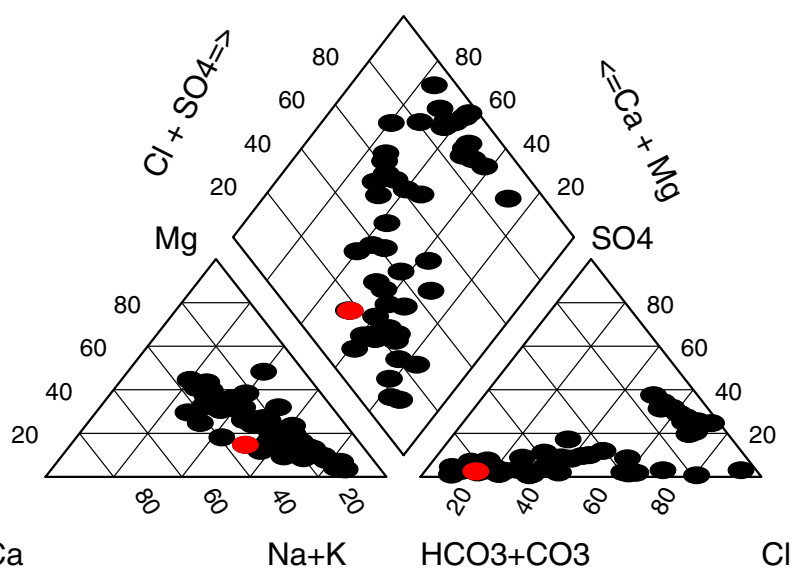

Fig. 4 Piper trilinear diagram

bearing minerals such as pyroxene, amphiboles, biotite, magnetite and olivine (Amadi et al. 1987). Oxygen transported into such layers, either by convection transport or direct exposure to air by lowering of groundwater levels results in oxidation of pyrite. Oxidation of pyrite, dissolution of these iron-bearing minerals and the decomposition of organic matter result in the release of acid, iron etc. into the soil and groundwater system (Jeong 2001; Chirenje et al. 2007). In this study, the $\mathrm{SO}_{4} / \mathrm{Cl}$ ratio is used as an indicator to illustrate potential pyritic oxidation. $\mathrm{SO}_{4} / \mathrm{Cl}$ ratio $\geq 0.5$ reflects pyrite oxidation. Table 1 shows that in areas with $\mathrm{SO}_{4} / \mathrm{Cl}$ ratios $\geq 0.5$ also have high $\mathrm{Fe}$ concentrations in the groundwater due to oxidation of pyrite.

This results in a decrease in $\mathrm{pH}$ and thus explains in part the mild acidity and elevated concentration of iron observed in the groundwater system. Also, the low values of sulphate concentration in the groundwater (Table 1) are attributed to the removal of sulphate from the water by 
Fig. 5 Relation $\mathrm{Na} /(\mathrm{Na}+\mathrm{Ca})$ vs TDS and between $\mathrm{Cl} /$ $\left(\mathrm{Cl}+\mathrm{HCO}_{3}\right)$ vs TDS diagrams indicating water-rock interaction

Fig. 6 Graphs of different parameters: a $\mathrm{Na}$ vs. $\mathrm{Cl}$, b $\mathrm{Ca}+\mathrm{Mg}$ vs. $\mathrm{SO}_{4}+\mathrm{HCO}_{3}$, c $\mathrm{Ca}+\mathrm{Mg}-\mathrm{HCO}_{3}-\mathrm{SO}_{4}$
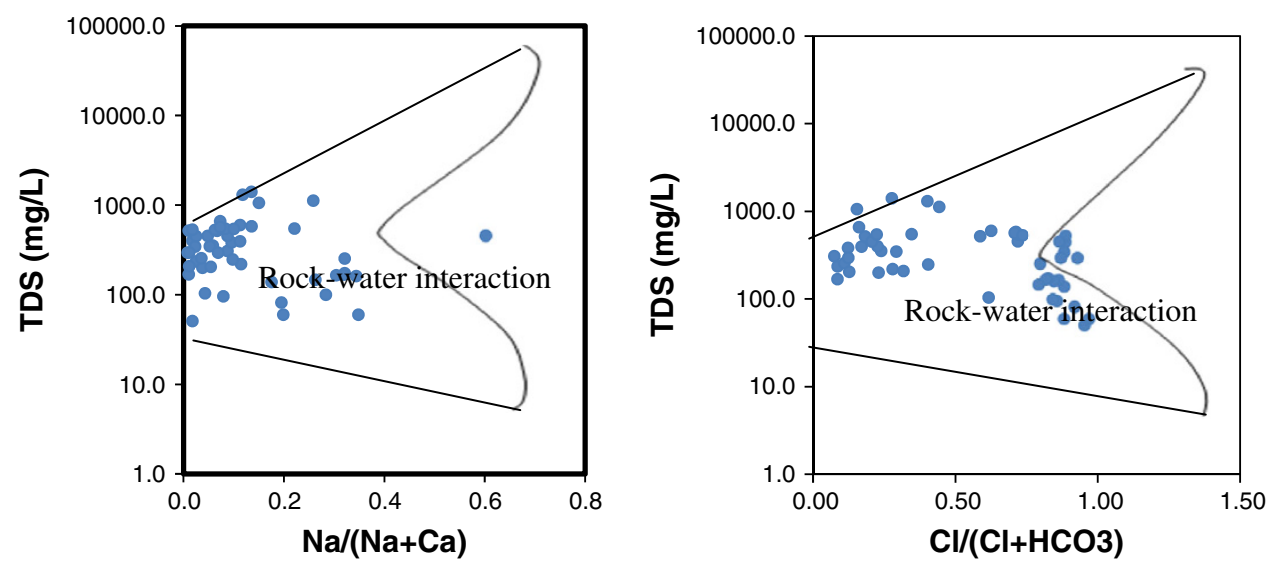
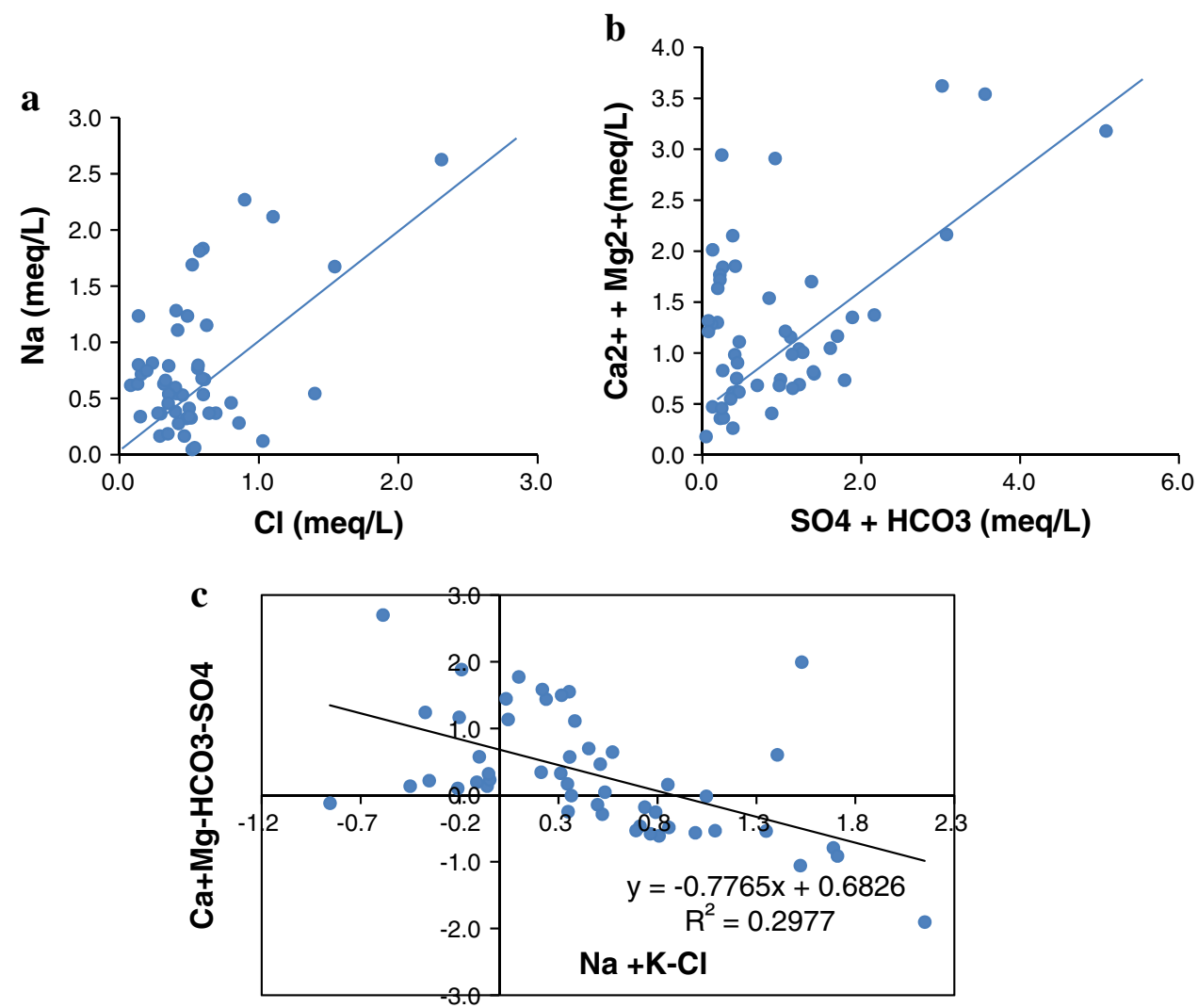

sulphate-reducing bacteria. The reduction of sulphate ions produces hydrogen sulphide; the unpleasant odour of which could easily be detected in the swamps of the Niger Delta (Amadi et al. 1987).

\section{Dissolution and deposition}

Mineral equilibrium calculations for groundwater are useful in predicting the presence of reactive minerals in the groundwater and estimating mineral reactivity (Deutsch 1997). Using the saturation index (SI) approach, it is possible to predict the reactive mineralogy of the subsurface from groundwater without collecting the samples of the solid phase and analysing the mineralogy (Deutsch 1997). In the present study, the calculated values of SI for calcite and dolomite of the groundwater samples range from -2.99 to 2.0 and -3.89 to 3.64 with averages of -0.32 and -0.27 (Fig. 7a, b), respectively. The groundwater samples were kinetically undersaturated to oversaturated with respect to calcite and dolomite, and were undersaturated with respect to gypsum (Fig. 7c).

\section{Principal component analysis}

The results of the principal component analyses are shown in Table 3. They include the loading for the rotated 
Fig. 7 Saturation indices a Calcite, b Dolomite, c Gypsum $\mathbf{a}$

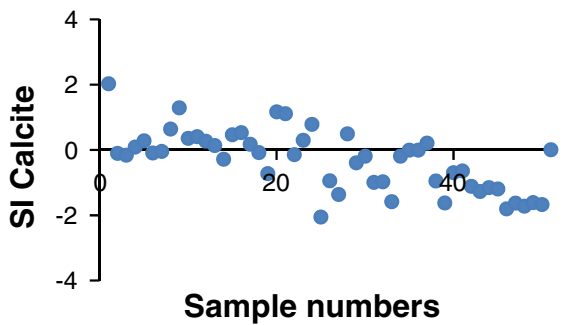

b

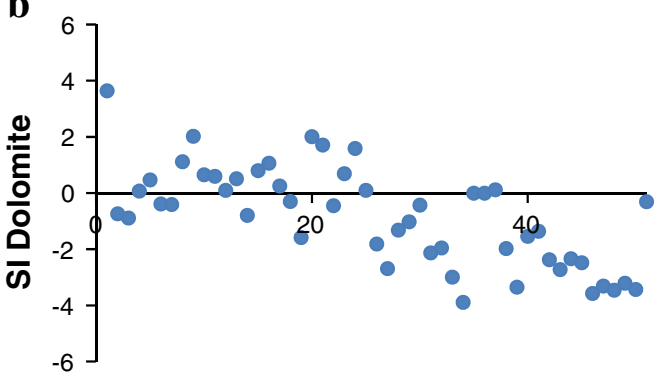

Sample numbers

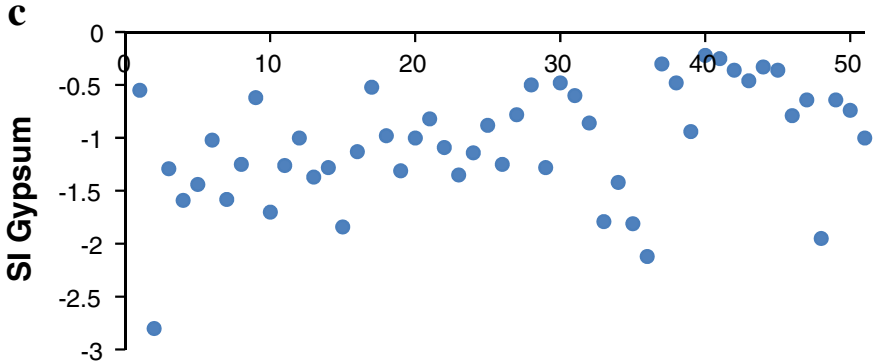

Sample numbers

Table 3 Rotated component matrix of chemical data of groundwater samples

\begin{tabular}{|c|c|c|c|c|}
\hline \multirow[t]{2}{*}{ Chemical variables } & \multicolumn{3}{|c|}{ Principal components } & \multirow[t]{2}{*}{ Communality } \\
\hline & I & II & III & \\
\hline $\mathrm{pH}$ & 0.351 & 0.297 & 0.401 & 0.372 \\
\hline $\mathrm{EC}$ & 0.959 & 0.068 & 0.084 & 0.931 \\
\hline TDS & 0.954 & 0.096 & 0.096 & 0.929 \\
\hline TA & 0.791 & -0.260 & 0.249 & 0.755 \\
\hline $\mathrm{TH}$ & 0.842 & 0.060 & 0.121 & 0.727 \\
\hline $\mathrm{Na}^{+}$ & 0.843 & -0.416 & -0.074 & 0.890 \\
\hline $\mathrm{K}^{+}$ & 0.829 & -0.280 & 0.002 & 0.765 \\
\hline $\mathrm{Ca}^{2+}$ & 0.842 & 0.250 & -0.302 & 0.863 \\
\hline $\mathrm{Mg}^{2+}$ & 0.489 & 0.576 & -0.325 & 0.676 \\
\hline $\mathrm{Fe}$ & 0.070 & 0.903 & 0.003 & 0.820 \\
\hline $\mathrm{Cl}^{-}$ & 0.616 & 0.112 & -0.609 & 0.764 \\
\hline $\mathrm{SO}_{4}^{2-}$ & -0.019 & -0.178 & -0.851 & 0.756 \\
\hline $\mathrm{NO}^{3-}$ & 0.177 & 0.867 & 0.117 & 0.796 \\
\hline $\mathrm{HCO}_{3}^{-}$ & 0.743 & -0.531 & 0.254 & 0.899 \\
\hline Eigenvalues & 6.613 & 3.502 & 1.642 & \\
\hline \multicolumn{5}{|l|}{$\%$ of variance explained } \\
\hline by component & 44.085 & 23.344 & 10.946 & \\
\hline Cumulative $\%$ of variance & 44.085 & 67.429 & 78.375 & \\
\hline
\end{tabular}

component matrix, the eigenvalues for each component, and the percent and cumulative percent of variance explained by each component and communality, indicating the proportion of variance of each variable controlled by the set of components. From Table 3, it can be seen that the first three principal components together account for
$78.38 \%$ of the total variance in the dataset, in which the first principal component explains $44.09 \%$ of the total variance, the second principal component exhibits $23.34 \%$ of the total variance, and the third principal component explains $10.95 \%$ of the total variance. The concentrations of EC, TDS, TA, TH, $\mathrm{Na}^{+}, \mathrm{K}^{+}, \mathrm{Ca}$ and $\mathrm{HCO}_{3}{ }^{-}$show high loadings (0.743-0.959), and the concentration of $\mathrm{Cl}^{-}$has moderate positive loading (0.616) on the first principal component. On the second principal component, Fe and $\mathrm{NO}_{3}{ }^{-}$concentrations have high positive loadings (0.867-0.903), and the concentration of $\mathrm{Mg}^{2+}$ shows moderate positive loading (0.576). The combinations of $\mathrm{Na}^{+}, \mathrm{K}^{+}, \mathrm{Ca}, \mathrm{HCO}_{3}{ }^{-}$and $\mathrm{Cl}^{-}$ions, influencing the high positive loadings observed on the first principal component (Table 3), suggest that the first principal component is associated with a combination of various hydrogeochemical processes that contribute to enrich more mineralized water (TDS).

For instance, a high positive loading of $\mathrm{Na}^{+}$and $\mathrm{K}^{+}$ions indicates natural weathering of rock minerals and various ion-exchange processes in the groundwater system. The strong loading of $\mathrm{HCO}_{3}{ }^{-}$ions with alkali and alkaline earth metals supports the view of natural weathering sources (Srivastava and Ramanathan 2008). The high positive loading of $\mathrm{HCO}_{3}{ }^{-}$is attributed to the reaction of feldspar minerals with carbonic acid in the presence of water (Elango et al. 2003). The concentrations of iron observed as high positive loadings on the second principal component (Table 3) are inferred to be related to the oxidation of inorganic sulphides including pyrite and leaching of ironbearing minerals such as pyroxene, amphiboles, biotite, 
magnetite and olivine (Amadi et al. 1987). Nitrate has no significant lithologic source in the study area and it must be associated with the anthropogenic activities. Factor 3 explained that $10.95 \%$ of the total variance is found to be associated with strong negative loading of $\mathrm{SO}_{4}{ }^{2-}$ and weak $\mathrm{pH}$. This factor may be attributed to anthropogenic activities such as domestic waste discharge.

\section{Conclusion}

The present study demonstrates the usefulness of factor analysis in combination with conventional graphical techniques in interpreting hydrogeochemical data to evaluate the major factors influencing groundwater composition. The degree to which the groundwater composition was influenced by various factors had been assessed by examining the factor scores. The hydrogeochemical characteristics of the groundwater revealed that the groundwater is slightly acidic and major anions and cations were below WHO prescribed limits for drinking water except iron. Prevalent water types in the study are: $\mathrm{Ca}-\mathrm{Cl}, \mathrm{Ca}-\mathrm{HCO}_{3}-\mathrm{Cl}, \mathrm{Ca}-\mathrm{Na}-\mathrm{Cl}, \mathrm{Ca}-\mathrm{Na}-\mathrm{HCO}_{3}-\mathrm{Cl}, \mathrm{Ca}-$ $\mathrm{Na}-\mathrm{HCO}_{3}$ and $\mathrm{Na}-\mathrm{HCO}_{3}$. The results of the multivariate statistical analysis in combination with conventional graphical methods indicate that the chemical composition of groundwater of the study area is strongly influenced by rock-water interaction, oxidation of inorganic sulphides including pyrite, weathering of silicates group of minerals enhanced by reverse ion-exchange processes. Weathering of silicate minerals controls the major ion chemistry of sodium, potassium, calcium and magnesium. The enhanced concentration of iron in the groundwater in the area is due to oxidation of pyrite and leaching of ironbearing minerals. Nitrate and chloride have no significant lithologic source in the study area and must be associated with the anthropogenic activities such as sewage wastes.

Acknowledgments The authors are grateful to all home owners who allowed us access to their premises to collect water samples from their domestic boreholes. Special thanks to Mr. Suoye Diete-spiff of the Central Research Laboratory, Niger Delta University for the physico-chemical analysis and two anonymous reviewers whose comments improved the quality of this paper.

Open Access This article is distributed under the terms of the Creative Commons Attribution License which permits any use, distribution, and reproduction in any medium, provided the original author(s) and the source are credited.

\section{References}

Akpokodje EG (1986) A method of reducing the cement content of two stabilized Niger Delta soils. Q J Eng Geol London 19:359-363
Amadi PA, Ofoegbu CO, Morrison T (1987) Hydrogeochemical assessment of groundwater quality in parts of the Niger Delta, Nigeria. Environ Geol Water Sci 14:195-202

Amajor LC (1991) Aquifers in the benin formation (MioceneRecent), Eastern Niger Delta, Nigeria. lithostratigraphy, hydraulics and water quality. Environ Geol Water Sci 17(2):85-101

APHA (1995) Standard methods for the examination of water and waste water (17th ed) American Public Health Association, Washington

Ashley RP, Lloyd JW (1978) An example of the use of factor analysis and cluster analysis in groundwater chemistry interpretation. J Hydrogeol 39:355-364

Cerling TE, Pederson BL, Damm KLV (1989) Sodium-Calcium ion exchange in the weathering of shales: implications for global weathering budgets. Geology 17:552-554

Chirenje T, Epstein C, Mueller R (2007) Water quality issues in the outer coastal plains New Jersy. In: Sarkar et al. (eds) Developments in Environmental Science, 5, pp 561-589

Davis JC (1986) Statistics and data analysis in geology, 2nd edn. Willey, New York

Davis SN, De Wiest RJM (1966) Hydrogeology. Wiley, New York

Deutsch WJ (1997) Groundwater geochemistry: fundamentals and application to contamination. CRC, Boca Raton

Durotoye B (1989) Quaternary sediments in Nigeria: In Kogbe (ed.) Geology of Nigeria, Rock View (Nigeria) Ltd. Publishers, Jos

Elango L, Rannan R, Senthil KM (2003) Major ion chemistry and identification of hydrogeochemical processes of groundwater in a part of Kancheepuram district, Tamil Nadu, India. J Environ Geosci 10:157-166

El-Sayed MH, Moustafa M, El-Fadl MA, Shawky H (2012) Impact of hydrochemical processes on groundwater quality, Wadi Feiran, South Sinai, Egypt. Australian J Basic Appl Sci 6:638-654

Fisher RS, Mulican WF (1997) Hydrochemical evolution of sodiumsulfate and sodium-chloride groundwater beneath the Northern Chihuahuan desert, Trans Pecos, Rexas, USA. Hydrogeol J 10:455-474

Garcia MG, del Hildalgo VM, Blessa MA (2001) Geochemistry of groundwater in the alluvial plain of Tucuman province, Argentina. Hydrogeol J 9:597-610

Gibbs RJ (1970) Mechanisms controlling World's water chemistry. Science 170:1088-1090

Guler C, Thyne GD, McCray JE, Turner AK (2002) Evaluation of graphical and multivariate statistical method for classification of water chemistry data. Hydrogeol J 10(4):455-474

Hem JD (1989) Study and interpretation of the chemical characteristics of natural water, 3rd edition. US Geol Surv Water Supply Paper 2254:263p

Jeong CH (2001) Mineral-water interaction and hydrogeochemistry in Samkwang mine area, Korea. Geochem J 35:1-12

Kogbe CA (1989) The cretaceous and paleogene sediments of southern Nigeria. In: Kogbe (ed.) Geology of Nigeria, Elizabethan Press, Lagos, pp 311-334

Krishnaraj S, Murugesan V, Vijayaraghaavan K, Sabarathinam C, Paluchamy A, Ramachandran M (2011) Use of hydrochemistry and stable isotopes as tools for groundwater evolution and contamination investigations. Geosciences 1:16-25

Lawrence FW, Upchurch SB (1982) Identification of recharge areas using geochemical factor analysis. Groundwater 20:680-687

Lee JY, Cheon JY, Lee KK, Lee SY, Lee MH (2001) Statistical evaluation of geochemical parameter distribution in a groundwater system contaminated with petroleum hydrocarbons. J Environ Qual 30:1548-1563

Lloyd JW, Heathcote JA (1985) Natural inorganic hydrochemistry in relation to groundwater, an introduction. Clarendon Press, Oxford

McLean W, Jankowski J, Levitt N (2000) Groundwater quality and sustainability in an alluvial aquifer, Australia. In: Sililo O (ed) 
Groundwater, past achievements and future chanllenges. Rotterdam, Balkenna, pp 567-573

Ofoegbu CO (1989) A review of the geology of the Benue Trough, Nigeria. J Afr Earth Sci 2:283-291

Okiongbo KS, Douglas RK (2013) Hydrogeochemical analysis and evaluation of groundwater quality in Yenagoa City and environs, Southern Nigeria. Ife J Sci 15:209-222

Okiongbo KS, Ogobiri G (2011) Geoelectric investigation of groundwater resources in parts of Bayelsa State, Nigeria. Res J Environ Earth Sci 3(6):620-624

Onyeagocha AC (1980) The petrology and depositional environment of the Benin Formation. Nigerian J Mining Geol 17:147-151

Reeder SW, Hitchon B, Levinson AA (1972) Hydrogeochemistry of the surface waters of the Mackenzie River drainage basin, Canada I. Factors controlling inorganic composition. Geochim Cosmochim Acta 36:825-865

Rogers RJ (1989) Geochemical comparison of groundwater in areas of New England, New York, and Pennsylvania. Groundwater 27:690-712

Ruiz F, Gomis V, Blasco P (1990) Application of factor analysis to the study of a coastal aquifer. Hydrogeol J 119:169-177
Schoeller H (1967) Qualitative evaluation of groundwater resources. In: Methods and techniques of groundwater investigation and development. Water Research, Series-33: UNESCO, pp 45-52

Short KC, Stauble AJ (1967) Outline of the geology of the Niger Delta. Bull AAPG 51:761-779

Srinivasamoorthy K, Chidambaram S, Prasanna MV, Vasanthavihar M, Peter J, Anandhan P (2008) Identification of major sources controlling groundwater chemistry from hard rock terrain-a case study from Mettur taluk, Salem district, Tamil Nadu, India. J Earth Syst Sci 117:49-58

Srivastava SK, Ramanathan AL (2008) Geochemical assessment of groundwater quality in vicinity of Bhalswa landfill, Delhi, India, using graphical and multivariate statistical methods. Environ Geol 53:1509-1528

World Health Organisation (WHO) (2004) Guidelines for drinking water quality: incorporating 1 st and 2nd vol. 1 recommendations 3rd ed., Geneva

Wright JB, Hasting DA, Jones WB, Williams HR (1985) Geology and mineral resources of West Africa, Allen and Unwin Limited, UK, pp 107 